\title{
Detection of Nuclear Protein Antigens to Antinuclear Antibodies in Serum of NOD Mouse
}

\author{
Toshiro ARAI, Kazue NOGUCHI, Nobuo MACHIDA, \\ Minoru SASAKI*, Yoshio OKI, and Kajuro KOMEDA** \\ Department of Veterinary Biochemistry, Nippon Veterinary and Zootechnical \\ College, 1-7-1 Kyonancho, Musashino, Tokyo 180, Japan, * Development Research \\ Laboratory, Banyu Pharmaceutical Co. Ltd., Saijo, Menuma, \\ Saitama 360-02, and ${ }^{* *}$ Division of Animal Research Center, \\ Tokyo Medical College, Shinjuku, Tokyo 160.
}

(Received 28 September 1988/Accepted 16 December 1988)

\begin{abstract}
Nuclear protein antigens to the antinuclear antibodies in serum of non-obese diabetic (NOD) mice were investigated. In the serum of diabetic NOD female mice ( 20 weeks old), the antinuclear antibodies were detected by indirect immunofluorescence assay using frozen sections of liver of $\mathrm{C} 57 \mathrm{BL} / 6 \mathrm{~J}$ or NOD mice as antigen. Nuclei were separated from the liver of $\mathrm{C} 57 \mathrm{BL} / 6 \mathrm{~J}$ mice and solubilized. Solubilized nuclear antigens were analyzed by SDS PAGE-Western immunoblotting techniques. Nuclear protein antigens with molecular weights of 26,000,32, 000 and 65,000showed strongly positive reactions with the antinuclear antibodies in the serum of the NOD mouse.
\end{abstract}

The inbred strain of non-obese diabetic (NOD) mice was established in Japan to study type I diabetes [9]. The incidence of spontaneous diabetes is influenced by sex, and more than $80 \%$ of females and less than $20 \%$ of males become overtly diabetic by 30 weeks of age. Despite the failure of all NOD mice to become overtly diabetic, mononuclear cellular infiltration to pancreatic islets (insulitis) is observed in over $95 \%$ of male and female NOD mice by 30 weeks of age $[4,10]$. It has been indicated that the autoimmune mechanism is mainly responsible for the insulitis and the following type I diabetes in this animal $[5,6,11]$. Antinuclear antibodies are frequently observed in sera of patients with systemic lupus erythematosus (SLE), a representative autoimmune disease $[2,3,8]$. Autoantibodies to DNA, histone, ENA (extractable nuclear antigen) and others have been classified, and their characteristics investigated $[8,13,14]$. On the other hand, various autoantibodies, including antinuclear antibodies to pancreatic cells, have been detected in the NOD mouse [12]. However, the nuclear antigens to the antinuclear antibodies have not been mentioned. In this study, expression of the antinuclear antibodies was investigated in the sera of NOD mice, and the protein antigens in extracts of liver nuclei were investigated by Western immunoblotting techniques.

Animals used in this study were bred under specific pathogen-free conditions in the Animal Research Center of Tokyo Medical College. Two female NOD mice aged 20 weeks had high concentrations of glycosuria for 6 weeks. Two other'female NOD mice without glycosuria (prediabetic) were 10 weeks old. Two female C $57 \mathrm{BL} / 6 \mathrm{~J}$ mice aged 12 weeks were used as a negative control. Animals were killed by decapitation and blood was taken from the jugular vein. Livers of animals were removed immediately and frozen at $-25^{\circ} \mathrm{C}$. Tissue sections of 8 to $10 \mu \mathrm{m}$ in thickness were cut in a cryostat from frozen blocks of livers. Indirect immunofluorescence assay (IFA) of the liver sections 
on the slide glass was performed by the method of Hijmans et al. [7]. The sera samples, diluted to $1: 10$ with phosphate buffer saline (PBS, pH 7.2 ), were mounted on the slide and incubated with the sections at $37^{\circ} \mathrm{C}$ for $1 \mathrm{~h}$. The sections on the slides were washed and incubated with FITC-conjugated sheep anti-mouse IgG (Jackson Immunoresearch Lab. Inc., PA, U. S. A.) at a $1: 100$ dilution at $37^{\circ} \mathrm{C}$ for $30 \mathrm{~min}$. The nuclei were separated from a homogenate of liver by the sucrose density gradient centrifugation method of Blobel and Potter [1] and solubilized with $10 \mathrm{mM}$ Tris- $\mathrm{HCl}$ buffer solution (pH 7.2) containing $0.15 \mathrm{M} \mathrm{NaCl}$ and $0.5 \%$ $(\mathrm{w} / \mathrm{v})$ Nonidet $\mathrm{P} 40$. For Western blotting analysis, the solubilized nuclear proteins were separated by sodium dodecyl sulfate polyacrylamide gel electrophoresis (SDS-PAGE), and electrophoretically transferred to nitrocellulose paper [15]. Some of the blotted papers were stained with Coomassie brilliant blue G immediately after transfer. The other blotted papers were blocked with $2 \%$ bovine serum albumin in $50 \mathrm{mM}$ Tris buffer saline (TBS), $\mathrm{pH}$

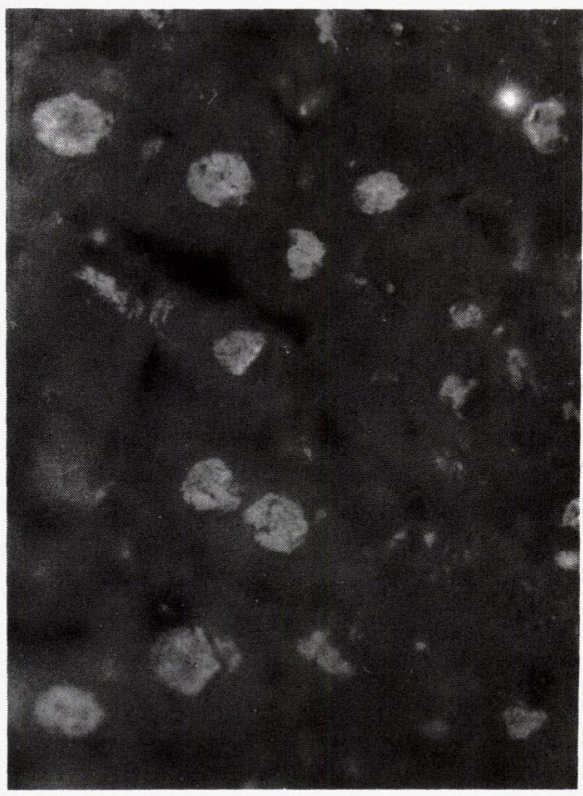

Fig. 1. Antinuclear antibodies in serum of NOD mouse detected by indirect immunofluorescence assay. A frozen section of liver of a C 57 $\mathrm{BL} / 6 \mathrm{~J}$ mouse was exposed to the serum of the diabetic NOD mouse, and the entire nucleus was stained by IFA $(x 400)$.
7.4 , at $37^{\circ} \mathrm{C}$ for $90 \mathrm{~min}$, then incubated at $37^{\circ} \mathrm{C}$ for 90 min with mouse serum diluted to $1: 20$, washed with TBS containing $0.05 \%$ Tween 20 , and again incubated with peroxidase-conjugated goat anti-mouse IgG (Jackson Immunoresearch Lab. Inc.) at a $1: 1000$ dilution at $37^{\circ} \mathrm{C}$ for 90 min. The papers were stained with TBS containing 4-chloro-1-naphtol $(0.5 \mathrm{mg} / \mathrm{ml})$ (Wako Pure Chemical Industries, Osaka, Japan).

The detection of antinuclear antibodies in sera of NOD mice by IFA is shown in Fig. 1. Frozen sections of liver of $\mathrm{C} 57 \mathrm{BL} / 6 \mathrm{~J}$ mice were exposed to the serum of diabetic NOD mice. Most nuclei of liver cells showed strong positive staining by IFA. The entire nucleus was stained by IFA, and it was considered that antigens were distributed nonuniformly throughout the nucleus. When liver sections of diabetic or prediabetic NOD mice were exposed to the sera of diabetic NOD mice, similar

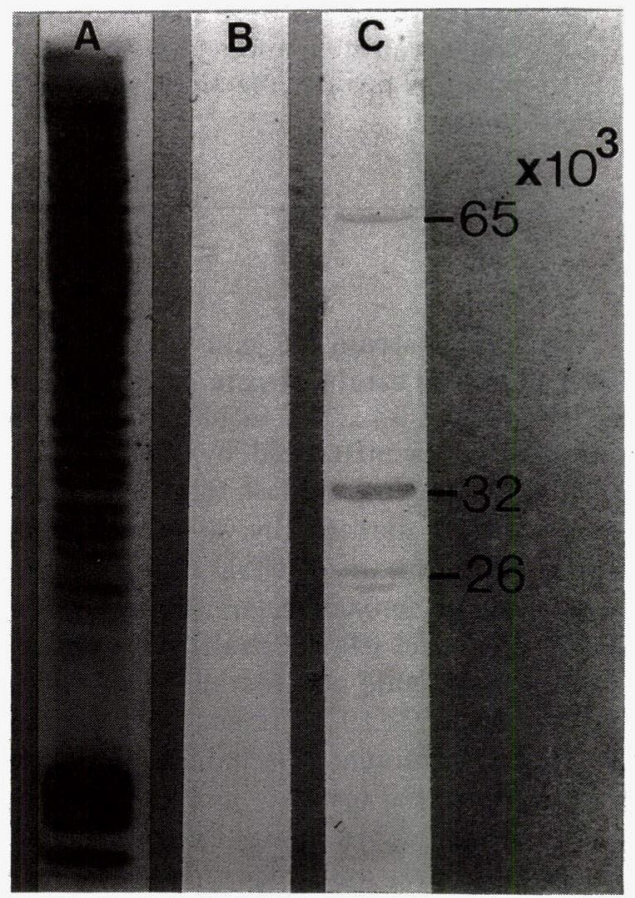

Fig. 2. Detection of protein antigens to antinuclear antibodies in the extract of liver nuclei by Western immunoblotting analysis A : nuclear proteins stained with Coomassie brilliant blue B:exposed to C $57 \mathrm{BL} / 6 \mathrm{~J}$ mouse serum (IFA negative serum) C : exposed to diabetic NOD mouse serum (IFApositi ve serum) 
staining was observed on IFA. On the other hand, when liver sections of diabetic NOD, prediabetic NOD or $\mathrm{C} 57 \mathrm{BL} / 6 \mathrm{~J}$ mice as antigen were exposed to the sera of prediabetic NOD or $\mathrm{C} 57 \mathrm{BL} / 6 \mathrm{~J}$ mice, no staining reaction was observed.

Twenty to 30 protein components of nuclear extract were detected by SDS-PAGE (Fig. $2-\mathrm{A})$. Three protein antigens with molecular weights of $26,000,32,000$, and 65,000 showed a strong positive reaction with the serum of diabetic NOD mice (IFA positive serum). The three protein antigens did not react with IFA negative serum of $\mathrm{C} 57 \mathrm{BL} / 6 \mathrm{~J}$ mice.

The antinuclear antibodies were detected in the sera of diabetic NOD mice. However, these antibodies were not detected in the sera of prediabetic NOD or C $57 \mathrm{BL} / 6 \mathrm{~J}$ mice. These antibodies reacted with nuclei of livers of NOD and $\mathrm{C} 57 \mathrm{BL} / 6 \mathrm{~J}$ mice. It has been reported that antinuclear antibodies in the sera of diabetic NOD mice react with nuclei of pancreatic cells [12]. These antibodies are not considered to be organ specific. Whether these antibodies are related to the onset of diabetes needs further investigation. Determination of immunoglobulin class and comparison of the antinuclear antibodies with autoantibodies observed in the sera of patients with SLE or other autoimmune diseases should be performed. It is suggested that the nuclear antigens to the antinuclear antibodies detected in this study are not JNA or histone, but nonhistone proteins like ribonuclear proteins based on the preparation or analytic method of antigens $[14,15]$. Further purification and characterization of the nuclear protein antigens should be performed.

\section{References}

[1] Blobel, G. and Potter, V. R. (1966). Science 154, 1662-1665.

[2] Casals, S. P., Friou, G. J., and Teague, P. O. (1963). J. Lab. Clin. Med.62, 625-631.

[3] Friou, G. J., Finch, S. C., and Detre, K. D. (1958). J. Immunol 80, 324-329.

[4] Fujino-Kurihara, H., Fujita, H., Hakura, A., Nonaka, K., and Tarui, S. (1985). Virchows. Arch.49, 107120.

[5] Hanafusa, T., Fujino-Kurihara, H., Miyazaki, A., Yamada, K., Nakajima, H., Miyagawa, J., Kono, N., and Tarui, S. (1987). Diabetologia 30, 104-108.

[6] Hari, J., Yokono, K., Yonegawa, K., Amano, K., Yaso, S., Shii, K., Imamura, Y., and Baba, S. (1986). Diabetes. 35, 517-522.

[7] Hijmans, W., Schuit, H. R. E., Mandema, E., Nienhuis, R. L. F., Feltkamp, T. E. W., Holborow, E. J., and Johnson, G. D. (1964). Ann. rheum. Dis. 23, 7377.

[8] Holborow, E. J., Asherson, G. L., Johnson, G. D., Barnes, R. D. S., and Carmichael, D. S. (1963). Br. Med. J. 3, 656-658.

[9] Makino, S., Kunimoto, K., Muraoka, Y., Miyazaki, Y., Katagiri, K., and Tochino, Y. (1980) . Exp. Anim. (Tokyo) 29, 1-13.

[10] Makino, S., Kunimoto, K., Muraoka, Y., and Katagiri, K., (1981) . Exp. Anim (Tokyo) 30, 137-140.

[11] Miyazaki, A., Hanafusa, T., Yamada, K., Miyagawa, J., Fujino-Kurihara, H., Nakajima, H., Nonaka, K., and Tarui, S. (1985). Clin. Exp. Immunol. 60, 622630 .

[12] Tarui, S., Hanafusa, T., Yamada, K., Kurihara, H., Miyagawa, J., Miyazaki, A., Nakajima, H., Asakawa, H., and Katsura, H. (1987). In Diabetic AnimalsTounyoubyou Doubutsu, pp. 56-63, Goto, Y. (edit.), Iyaku Journal, Tokyo.

[13] Tan, E. M. (1982). Adv. Immunol 33, 167-240.

[14] Tojo, T., Mimori, T., Okano, Y., and Ogasawara, T. (1988). Physico-Chem Biol 32, 1-6.

[15] Towbin, H., Staehelin, T., and Gordon, J. (1979). Proc. Natl. Acad. Sci. U. S. A 76, 4350-4354. 


\section{NOD マウス血清中の抗核抗体に \\ 対する核蛋白質抗原の検索}

新井敏郎・野口和江・町田伸生・佐々木 稔* 大木与志雄・米田嘉重郎**

日本獣医畜産大学獣医生理化学教室

*萬有製薬株式会社開発研究所

**東京医科大学動物実験センター

やせ型糖尿病 (NOD) マウス血清中の抗核抗体に対す る核蛋白質抗原について調べた。C 57 BL/6 J および NOD マウスの肝凍結切片を抗原として用いた間接蛍光 抗体法により，尿桾陽性の雌 NOD マウス（20週秢）血 清中に抗核抗体が検出された。この血清を用いて，C57
$\mathrm{BL} / 6 \mathrm{~J}$ マウスの肝から分離一抽出した可溶化核蛋白質 抗原を SDS-PAGE Western immunoblotting 法に より検索した結果, 分子量 65000，32000，26000の蛋白 質が NOD マウス血清中の抗核抗体と特異的に反応し た。 